\title{
8 \\ Searching for a Khmer Monastic Higher Education in Post-Socialist Vietnam
}

\author{
Philip Taylor
}

In 2015 I met a 32-year-old man from a small village in Trà Vinh, a province of the Mekong Delta which is home to many of Vietnam's ethnic minority Khmer. He had grown up in a family of landless farmers in a village that only recently had been connected to a sealed road. Like many Khmer students in this remote and impoverished province, he had dropped out of state school after only five years, and his Vietnamese was not good. He had, however, studied for several years in temple schools in his district where, while ordained as a monk, he had learnt to read and write Khmer. The Buddhist temples in his home province are linked in an educational network comprising 144 campuses that provide schooling in numerous subjects up to Grade 12. Despite its size and sophistication, this autonomous, religious-based education network is relatively obscure, even among Vietnamese people, for the education it provides is entirely in Khmer.

After we had exchanged preliminary greetings in Khmer, he astonished me by breaking into fluent English. Details of an unusual biography emerged. In 2000 he had graduated from the top level of the monastic system but, unsatisfied with the narrowness of the curriculum, he had crossed the border illegally to Cambodia to continue his studies. He wanted to learn more about history, he said. At that time, 
Vietnam did not have a university for Khmers and his elderly Pali teacher had advised him to go to Cambodia, saying that he would learn nothing about his Khmer heritage in Vietnamese state schools. While still ordained as a monk he studied Khmer literature and English for Buddhism for his BA in the main Buddhist university in Phnom Penh. Four years later, a laywoman sponsored him to do further studies in Thailand. He learnt Thai and did his MBA in the English language. Then he returned to Phnom Penh where he disrobed, married, and started work as an office manager in an English-speaking foreign firm. He now owns a car and a house in Phnom Penh and does charity by raising money for scholarships for poor Khmer Krom students. His biggest regret is not being able to work in his home province, owing to the fact that he had left his birth country illegally.

The story of this young man illustrates the capacity of higher education to promote mobility into the urban middle class. By 2015, it was becoming common for Khmer people from disadvantaged rural areas of the Mekong Delta who had been through state schooling to establish themselves in large Vietnamese cities, although it was still rare to meet people from such a background working as a manager in an English-speaking office, let alone owning a house and car. The most intriguing feature of this man's impressive story of social mobility was that he had not studied beyond the primary level of state school, had never resided in a Vietnamese urban area, and was scarcely literate in the national language. Yet he had two post-secondary degrees, had studied in two capital cities, and was fluent in two foreign languages. His remarkable passage out of rural obscurity had proceeded via a vernacular education network that connects the Khmer-speaking margins of the Mekong Delta to the metropolitan centres of Theravada Asia. For 16 years he had studied and resided in the temples of this transnational network, his living and study costs provided by Khmer Buddhist laypeople. Tellingly, however, his story also can be read as a failure to progress in Vietnamese-speaking educational and social spheres. Not only had he failed to exit the ethnic bubble in which Vietnam's Khmer minority are enclosed, his illicit educational voyages had eroded his employment prospects in his home village, resulting in a demotion in his status even in narrowly local terms.

The vernacular Buddhist education systems of the Theravada world are defined by this tension between parochialising and cosmopolitan characteristics. In Thailand, monastic education played a key 
role in the 'integrative revolution' (Geertz 1963) and was used by a centralising Thai state to promote identification with a transcendent national polity and supplant alternative local, religious or ethnic identifications (Keyes 1971; Tambiah 1976). Similar concerns informed the French colonial effort in Cambodia to propagate a standardised notion of Khmer identity in the curriculum used in Buddhist temple schools. The purpose of such efforts was to inculcate in students a sense of loyalty to the French protectorate of Cambodge and replace attachments to Siam as a civilisational centre. Such a project was conceived and coordinated through the auspices of the Buddhist Institute in Phnom Penh, which served as the headquarters for formulating the curriculum, training teachers, and disseminating curricular materials (Edwards 2007). ${ }^{1}$ These activities shed light on the paradoxical uses of Buddhist education institutions as centres for the inculcation of transcendent subjectivities that, contradictorily, serve to parochialise their subjects and foreclose alternative transcendent attachments.

Often the impetus to construct such institutions has been a moment of cultural crisis. For instance, Anne Hansen traces the inception of the modern system of Buddhist learning in mid-nineteenth-century Siam to King Mongkut's doubts about the validity of his own ordination, which set him to amassing the knowledge and expertise that would enable him to authenticate his status as a Buddhist cleric. Similarly, the nineteenth-century monastic pioneers of the Khmer Buddhist higher education system who repatriated the new Siamese learning to Cambodia did so out of the dire sentiment that their tradition had been denuded and debased after decades of war and occupation (Hansen 2007:49-50, 84-96). Key Khmer contributors to the Buddhist Institute were beset by a premonition that their cultural and religious tradition was about to be extinguished by mass conversions to the new Cao Đài faith centred in Vietnam (Edwards 2007:197-209). These institutions that set Buddhist education on new foundations crystallised the solutions forged by a founder figure to a crisis of cultural reproduction and renewal. They emerged in an era when the legitimacy of the old was threatened by the new, in zones such as former royal capitals and

1 Justin McDaniel has described concurrent initiatives in the French protectorate of Laos to redesign monastic learning so as to neutralise the appeal of Siamese Buddhist education among Lao student monks and promote identification with the cultural and spatial construct of French Indochina (McDaniel 2008:38-52). 
urban centres where cultures were in collision, and they issued from the cultural elites of the old order for whom the need to find new modes of legitimacy was at its most urgent.

If we adopt the perspective of students, we see such institutions in a different light. Scholars have noted that the monastic educational networks that centred on Bangkok and Phnom Penh were used by youths from peripheral rural regions as an avenue of social mobility (Wyatt 1966; Kalab 1976). The Buddhist universities of Bangkok served as stepping stones for disadvantaged rural students to gain access to the wealth of specialised knowledge and employment opportunities that exist in the metropolitan centre (Kabilsingh 1986). From the vantage point of late nineteenth-century Cambodia, the Siamese metropolis obtained a very different significance as a charismatic centre that exerted a magnetic pull over students as a symbol of modernity, the pure source of culture, magical texts, and enlightened teachers (Hansen 2007:79-96). The central node of these monastic educational networks thus served an exemplary centre that offered students the experience of authentic self-knowledge, transcendence, or salvation. Drawing a leaf from the experience of Muslim Southeast Asians who travelled to Mecca on educational journeys, we can postulate that for Theravada Buddhists, pilgrimages to their own metropolitan institutions of higher learning conferred distinction, power, and an aura of the sacred upon those who returned from such sites. ${ }^{2}$ In short, these institutions derive their vitality from the periphery itself for which they serve, in one guise or another, as the charismatic centre.

The situation is more fragmented for the Khmer Krom, an ethnic and religious minority in Vietnam with complex historical relations to several states (Taylor 2014). As in other Theravada Buddhist contexts, the Khmer Krom have a vernacular education system centred on a network of Buddhist wats, which, among other purposes, serve as local schools and as a pathway to advancement in wider society. Despite long-standing linkages to religious centres in South and Southeast Asia, the Khmer Krom live in a country where Theravada Buddhism is a minority creed and has never attracted significant state patronage. As former subjects of the Khmer kingdom, they identify culturally with Khmers in Cambodia, while they are divided from 
modern Cambodia by a political border. As citizens of Vietnam, they are compelled to enrol in state education whose focus has been to inculcate a sense of belonging to a nation whose centre lies in faraway Hà Nội. With religious, cultural and political affiliations that seemingly pull in different directions, it is of interest to know what significance the Khmer Krom attach to these disparate civilisational projects, and what role has been played by their vernacular educational institutions in connecting or disconnecting them from the plurality of centres under whose sway they come.

In the second quarter of the twentieth century, a concerted effort was made by the French to draw the hundreds of Khmer temple schools in the Mekong Delta into the orbit of the Buddhist Institute in Phnom Penh, which both disseminated ideas of their membership in a Khmer cultural tradition and served as a peak destination for their educational journeys. With the demise of colonialism in the mid-1950s, the institutional link to Cambodia was severed. However, during the decades of nation-building and war in Vietnam, numerous Khmer Krom students and monks continued to undertake educational pilgrimages to Cambodia. With the rise of communist states in Indochina in 1975, monastic education in both countries was plunged into a severe crisis. In Cambodia, it disappeared. In Vietnam, repressed by the government, and with a curriculum that offered students no prospects for advancement in the broader society, the Khmer monastic education system faced extinction. ${ }^{3}$ After a crisis lasting 30 years, several initiatives were launched by Khmer monastics in Vietnam to fight their way out of parochialisation and irrelevance, relink Khmer temple schools in Vietnam to peak educational destinations in the Theravada Buddhist world, and stimulate a flow of students.

Coming to a head in the first decade of the twenty-first century, such initiatives gave rise in quick succession to no less than three alternative higher education destinations: in Thailand, Cambodia, and within Vietnam itself. This sudden multiplication of higher education pathways after three decades in which none had existed offers revealing insights into the numerous actors and contradictory pressures that shape the Khmer monastic field in Vietnam. Each of these pathways attracts a significant number of students, which signals

3 The situation of monastic education in socialist Laos after 1975 is discussed by Justin McDaniel (2008:52-68) and Martin Stuart-Fox (1996). 
the thirst that exists among Khmers in Vietnam for higher education, and the willingness of Khmer students to try different ways to achieve it. Examining the relative popularity of these different routes offers a sense of the competing desires that shape these educational quests. The fact that the most-trodden route is illegal and that the officially sponsored route is the least favoured suggests that the government's ability to steer monastic education from the top down is limited. Similarly, Khmer monastic authorities' attempts to craft an entirely new educational pathway have attracted only limited support from state authorities and individual students. By tracing the educational journeys taken by Khmer Krom students, one can understand the ambitions and frustrations that shape from below the institutional contours of Khmer monastic higher education in Vietnam.

This chapter describes the search for a viable monastic higher education pathway for the Khmers of Vietnam's Mekong Delta. Charting the decline and partial rehabilitation of Cambodia as their peak educational destination, it also documents the alternative destinations that have emerged over the course of the last decade. By focusing on the agency of state authorities, monastic leaders, and students, the chapter shows how the field of monastic higher education has been shaped in a negotiation between multiple actors with competing priorities. Having once been oriented towards Cambodia as the peak destination of their vernacular tradition, Khmer Krom students now enjoy tenuous access to a variety of educational centres, none of which satisfies the aspirations nursed by them, or by religious or state elites, for Khmer higher education in Vietnam. ${ }^{4}$

4 This chapter draws on research conducted in Vietnam and Cambodia over multiple visits between 1999 and 2015 funded by the Australian Research Council and ANU College of Asia and the Pacific. I thank David Chandler, John Marston, Roger Casas, and Sango Mahanty for their comments and assistance with this chapter. Conversations with numerous Khmer Krom intellectuals, monks, abbots, and political leaders provided me with valuable insights into the concerns that have informed a long history of monastic educational reform. Collected life histories of students spanning 70 years of educational travel to Cambodia and observation of activities in many learning institutions gave me a sense of the aspirations and frustrations that have informed student's selection of educational options. 


\section{Closing the Educational Route to Cambodia}

The Khmer Krom, or ethnic Khmer people of Vietnam, number over a million and live primarily in the Mekong Delta of southern Vietnam (Taylor 2014). They have a deep-seated historical connection to Cambodia, dating to when the Mekong Delta was part of the Khmer kingdom. Even after the Mekong Delta came under Vietnamese and French administrative control, Khmers of this region continued to be integrated culturally with Khmers in Cambodia. One feature of this integration was an education system based in Theravada monasteries that was identical to that found in Cambodia. A French report in 1903 observed that in every Khmer Buddhist temple in the province of Trà Vinh, a monk was in charge of educating local children to read and write Khmer and to do basic maths. In the early 1880s, a system of public schools had been set up by the colonial authorities 'to propagate the French language and serve as an instrument of civilisation', but these schools were mostly attended by 'Annamite' (ethnic Vietnamese) children. The report notes that the task of getting Khmers into state schooling was 'delicate, owing to the fact that Khmer fathers preferred their children to study under a monk in the local temple' (Société des Etudes Indochinoises 1903:41-42).

Despite this apparent conservatism, major changes to the monastic education system occurred during the colonial period. Around 1930, the French began to introduce in selected temple schools in Cochinchina the renovated temple school model that had been introduced in Cambodia. According to Louis Mallaret, by 1944, there were 209 schools of this type in Cochinchina, with a total of 7,274 students, of whom 1,093 were girls (Malleret 1946:29). As Penny Edwards notes, the curriculum in these schools included textbooks on Khmer history, geography, language, and other secular subjects that had been developed under the auspices of the Buddhist Institute in Phnom Penh (Edwards 2007:177-182). This curriculum promoted ideas about Cambodian history, culture, and geography that were to become foundational to nationalist ideas about Cambodian identity. Between 1929 and 1933, noted Phnom Penh-based monastic leaders Ven. Huot Tath and Ven. Chuon Nath travelled to Cochinchina on tours of inspection, establishing schools and distributing books 
(Edwards 2007:188-190; Harris 2009:107-108). For the next half century, Khmer monastery schools of the Mekong Delta had the same curriculum and used the same textbooks as those in Cambodia.

By the 1930s, Khmer monks from the Mekong Delta were travelling to Cambodia to undertake teacher training and higher studies. Malleret notes that monks who taught in the renovated temple schools in Cochinchina would go to Phnom Penh, Trà Vinh, and Sóc Trăng to undertake vocational teacher training (Malleret 1946:29). Harris mentions that, in 1931, some 30 Khmer Krom monks spent a year in Cambodia to undertake teacher training for the reformed Buddhist schools (Harris 2009:108). Khmers from Cochinchina also studied for longer periods of time in the protectorate's two elite educational institutions, the École Supérieure de Pali (Pali high school, established in 1922), and the Buddhist Institute (established in 1930). A wellknown instance of this was the founding member of Cambodia's communist movement, Tou Samouth. Born in Trà Vinh in 1915, he was educated as a Buddhist monk at the Buddhist Institute in Unnalom Monastery, Phnom Penh, where he also taught Pali until the mid-1940s (Kiernan 1981:163). ${ }^{5}$ In the course of my own research in Vietnam, I met an elderly man from Sóc Trăng who had ordained and studied Pali and French in the École Supérieure in Phnom Penh for 30 years, from the 1940s to the 1970s. One man born in Trà Vinh in 1925 had studied French and Khmer in Trà Vinh for seven years, after which he was ordained and went to Phnom Penh, where he studied for another four years in Wat Unnalom. Another man born in Kiên Lương in 1940 had studied Sanskrit, Pali, French, and English in Phnom Penh for four years, from 1959-63.

Of the $25 \mathrm{Khmer}$ Krom people whose biographies of educational travel to mid-twentieth-century Cambodia I collected, around half had gone to study in state schools. Cambodia was attractive to the Khmer Krom as an educational destination because instruction was in Khmer and French rather than in Vietnamese. By the end of the Second World War, there were only 19 official Franco-Khmer elementary schools in the whole of Cochinchina (Malleret 1946:29), and just one lower secondary school, in Cần Thơ. Meanwhile, Cambodia had several

5 Another Trà Vinh-born founding member of Cambodia's communist movement, Achar Mean, later known as Son Ngoc Minh (b. 1920), also taught in Unnalom Monastery in the early 1940s (Kiernan 1981:163). 
secondary and higher-level studies institutions, such as the College Preah Sihanouk in Kompong Cham, the Lycée Sisowath in Phnom Penh, ${ }^{6}$ and the Teachers' College in Phnom Penh. ${ }^{7}$ In the 1940s and 1950s, several of my elderly interlocutors had gone on to higher-level studies in Cambodia after completing elementary or lower secondary Franco-Khmer schooling in Cochinchina. Others went directly to Cambodia to study at elementary level. These state school students tended to come from moderately wealthy to wealthy families. I also met many Khmer Krom who, after South Vietnam was founded as a republic in 1955, had studied in state schools at the primary and secondary level in the provinces of Kompong Thom, Kampot, Takeo, Kompong Cham, and Phnom Penh.

Cambodia was attractive to Khmer Krom students because of the vibrancy of its Khmer-language public sphere, the breadth and depth of its labour market, and, after 1960, the haven it offered from conscription and war in Vietnam. Having completed their studies in the monastic or secular streams, many Khmer Krom students remained in Cambodia to work and assume social leadership positions. The bestknown exemplars of this trend are the Cambodian political leaders Son Ngoc Thanh (b. 1908), Tou Samouth (b. 1915), Son Ngoc Minh (b. 1920), Ieng Sary (b. 1929), and Son Sen (b. 1930), all of whom were born in Trà Vinh then lived and worked for the rest of their careers in Cambodia. I met several elderly Khmer Krom who had commenced their education in temple schools in the Mekong Delta, and spent the 1960s and 1970s teaching in Cambodia. Some became distinguished teachers and abbots in Buddhist temples. Others taught foreign languages in state schools in Phnom Penh, Battambang, Takeo, and other places. Obtaining skilled work of this kind in the urban centres of Cambodia was an exceptional accomplishment for the children of farming families from a marginalised minority in the Mekong Delta. We see here a good example of the role of the monkhood in Khmer society as an avenue of social mobility (Kalab 1976). The opportunity for social advancement provided by monastic education undoubtedly was one of the factors that made ordination attractive to rural youths.

6 One of its alumni was Khmer Rouge leader Ieng Sary, born in Trà Vinh in 1929. He commenced his studies in 1945.

$7 \quad$ Khmer Rouge leader Son Sen, born in Trà Vinh in 1930, commenced studying there in 1946. 
Not all of these students stayed in Cambodia. When they graduated from higher studies, many returned to Vietnam to work, teach, marry, and assume leadership positions in the monastic system and wider society. Those who had studied in Cambodia returned with their prestige and position in the Khmer community considerably enhanced. Of the 15 returnees whose biographies I collected, two went on to lead the monastic resistance against the South Vietnamese regime in the 1960s, two became special forces commanders, and three assumed high-level positions in the new regime after 1975, while others became respected abbots, meditation teachers, and ritual specialists. Two disrobed, married, and returned to farming. They also made a critical contribution to reproducing the monastic education system. All but one of the returnees contributed to teaching subjects such as Pali and Khmer literacy and foreign languages to the monks and lay children in their local temples.

Such educational passages came to an abrupt end in 1975 when Communist regimes came to power throughout Indochina. In Democratic Kampuchea, the Khmer Rouge emptied the cities and terminated diplomatic relations with many countries. Their peasant troops closed down schools, destroyed books, banned the speaking of foreign languages, and put to death many intellectuals. The monkhood was terminated, temples were used as storehouses and granaries, and former monks and teachers were disrobed and put to work along with urban and educated people, planting rice and undertaking agrarian earthworks in collective farms. People identified as Khmer Krom were persecuted and eliminated (Kiernan 1996; Chandler 2008; Harris 2012). I was told about several Khmer Krom teachers and abbots who had stayed on in Democratic Kampuchea and later perished under the Khmer Rouge.

Vietnam's communist resistance movement had worked closely with Khmer Krom monastic leaders during the Vietnam War. This alliance had helped keep Khmer monastic education functioning in Trà Vinh and other provinces in the face of repression by the South Vietnamese state. However, once the communist government assumed formal power in southern Vietnam in 1975, efforts were made to reduce the hold of monasteries in Khmer life. Khmer monks were required to undertake heavy agrarian labour, and the alms round was suppressed. A systematic attempt was made to terminate the monastic education program by confiscating books, forbidding classes, and imprisoning 
monks who continued to teach. Through determined covert actions and tight solidarity, and under the leadership of communist-affiliated clerics and officials, Khmers managed obstinately to continue their classes for up to 10 years after liberation. However, in the mid-1980s, the Vietnamese government cracked down, arresting teachers, abbots, and the educational resistance movement's leading figures, several of whom died mysteriously in jail. The monasteries were raided and surrounded, and all teaching came to a halt, for up to 10 years in some localities. ${ }^{8}$

In the late 1980s, classes in the Khmer monastic education program reopened in attenuated form. The initial classes were small and lowkey and were conducted in select monasteries in remote parts of Trà Vinh Province where Khmer Krom members of Vietnam's communist party were concentrated. The new curriculum consisted of 12 religious and Khmer-language subjects. ${ }^{9}$ Gone were the subjects of Cambodian geography, history, and civic morality and citizenship, as well as French and English. Students had to contend with the complete absence of Khmer-language texts and classroom study materials, which had been confiscated and destroyed in the period before 1985. Initially, teachers transcribed study materials into notebooks from memory or surviving texts, which were then repeatedly copied by hand. By the late 1990s, study texts for all 12 grades of the syllabus were being smuggled furtively from Cambodia and endlessly re-photocopied, replenishing monasteries in Vietnam with a reservoir of faint and sometimes illegible facsimiles of the original Cambodian texts.

When classes recommenced, they drew critically on the resources of Khmer intellectuals who had survived the crackdown and had remained in the country. Hundreds of members of the Khmer Krom intelligentsia who had participated in the resistance movement had fled the country. Many survivors were too cowed to resume a life of educational service. Initially, classes were taught from memory by weather-beaten lay teachers who returned to classrooms from the rice fields. In this culturally sparse environment, the cultural knowledge

8 Brief references to this resistance movement and crackdown can be found in Harris (2009). This compressed summary draws on interviews conducted with numerous participants in the movement, which I hope to be able to write up on another occasion.

9 These included Khmer literacy, grammar, reading, dictation, composition and maths; Buddhist doctrine, history and monastic law; Pali literacy and grammar; and Pali-Khmer translation. 
possessed by those who had once studied or spent time in Cambodia was prized and became a crucial element in the regeneration of Khmer monastic education in Vietnam. However, these were people who had been in Cambodia long ago, and thus the bridge to that country they represented was vestigial.

In post-Khmer Rouge Cambodia, the monkhood had been reconstituted in the early 1980s (Keyes 1994; Marston 2014), but ordinations were tightly restricted for the remainder of that decade and only in 1989 was the first Buddhist primary school in Cambodia officially reopened (Sovanratana 2008:258-259). Buddhist education in Cambodia began its renaissance in the 1990s, with the opening of a high school in 1992 and the reopening of Preah Sihanouk Raja Buddhist University in 1999. By 2005, Cambodia could count 555 Buddhist primary schools, 23 Buddhist secondary schools, and two Buddhist universities (Sovanratana 2008:259-264). Secular higher education institutions in Cambodia were revived and restructured in the 1990s under the country's internationally sponsored reconstruction. In the next decade, the number of universities and colleges mushroomed with the entry of numerous private education providers. By 2007, there were 62 higher education institutions in Cambodia, of which 40 were private. Three decades after the Khmer Rouge had almost wiped out the country's intellectual elite, higher education in Cambodia was again booming, with 45,000 students enrolled in a great array of degree programs in public, private, and religious institutions (Chealy 2009:154-160).

The cultural and educational renaissance underway in Cambodia did not go unnoticed among the Khmers of the Mekong Delta. Senior abbots and Khmer government officials making approved official trips brought home news of Cambodia's reconstruction. Via relatives and news media, Khmers in the Mekong Delta were able to follow the news of the rebuilding of temples, the resurgence of education, Cambodia's vibrant cultural and festive life, the explosion of publications, media and arts, the growth of international tourism, and reconstruction of museums and ancient monuments. By the late 1990s, monks who had completed the monastic high school level in Vietnam were also contemplating the prospects of further education. With the opening of Buddhist universities in Phnom Penh, Cambodia again beckoned as an appealing higher education destination. 
However, at that time Khmer Krom monks were prohibited from travelling to Cambodia to study. Applications for passports and travel permits were denied or inexplicably held up indefinitely. Monks who applied were told that it was impossible to travel to Cambodia; their lives would be endangered, for Cambodia lacked laws and security. Monks who went to Cambodia to study would be breaking the law. When I began conducting research in Trà Vinh in the late 1990s, the bans on Khmer Krom monks travelling to Cambodia was one of the most heated topics of conversation. I was often told of monks who had tried to go illicitly but had been arrested at the border. Some had made it into Cambodia but had been arrested and defrocked on their return. Those who returned from an illegal sojourn in Cambodia were punished in other ways, invited by the police for questioning, surveilled, denied permission to take up residence again in their home temple as a monk, or denied work or promotion.

As one monk told me in 1999, being a Khmer monk is what made it hard to go to Cambodia, rather than being Khmer per se:

The government now tolerates trade, or the movement of people with business or investment projects: anything which is of purely economic benefit to Vietnam. However, they never give permission to Khmer monks.

They are worried that because monks have the time to study their culture and their country's history, meet with other monks and discuss their situation, they are more likely to engage in politics. They might meet up with the Cambodian government and opposition and take part in resistance to Vietnamese rule. Since traders and small business people haven't the time or the education to develop a broad picture of their people's plight they don't represent the same threat. These restrictions are what the government calls 'precautionary' measures. In fact monks here are too afraid to take part in such activities.

Only in the mid-2000s were Khmer Krom monks permitted to travel to Cambodia, on a tourist visa, but the period of time they were allowed to stay there was short. Travelling for the purpose of study remained out of bounds. As one group of student monks from Trà Vinh told me in 2005, the reason Vietnam prevents Khmer monks from travelling to Cambodia to study is that the government probably does not want them to be influenced by the environment of anti-Vietnamese politics in Cambodia. 


\section{Consequences of Closing the Cambodian Study Route}

The ban on monks continuing their studies in Cambodia aroused in Khmer Krom students an intense sense of being denied access to crucial aspects of their cultural heritage. Aware that the curriculum they had studied had been shorn of several important subjects, many suspected that they lacked adequate knowledge of Khmer culture and society and about the history of the localities they called home. Thus many had cause to doubt that they truly knew who they were, let alone being able to claim status as well-educated people. Having had access to only a handful of photocopied school textbooks during their years of monastic study, many students yearned for exposure to a fuller spectrum of Khmer-language texts in the disciplines they had studied. All were aware that in Cambodia, the Khmer language was the medium of a diverse and dynamic public sphere and media, popular culture, and the arts. As opposed to Vietnam, where Khmer script had no purpose other than as a subject for study by Khmers in their temples, in Cambodia the written word was living, functional and highly developed and central in many walks of life. Many student monks I spoke to expressed regret that by being denied the opportunity to study in Cambodia, they were deprived of complete and authentic experience of their own culture.

At the same time, closure of the border prevented monks who wished to specialise intensively in the study of Buddhism from accessing high-quality education in that field. In late 2006, monks in Trà Vinh who aspired to deepen their understanding of Buddhism told me:

The monastic schools in Cambodia are better than those in Vietnam because they concentrate on Pali, Sanskrit, Buddhism, Buddhist history, and Pali-Khmer translations. Here, Khmer language and culture subjects take up a large part of the curriculum because these subjects are not taught at all outside of our temples. Plus Cambodia has two Buddhist universities that allow one to specialise more deeply in Buddhist subjects.

A number of Khmer Krom monks have enrolled to study in the Buddhist university in Hồ Chí Minh City, which reopened in the 1980s, following its closure in 1975, and now offers undergraduate and post-graduate level courses. However, this option was not considered 
satisfactory by the Khmers with whom I spoke, since the instruction and curricular study materials are entirely in Vietnamese. They noted that emphasis in the curriculum is on the development of Mahayana Buddhism as a Vietnamese national tradition, and on Buddhism in Vietnamese history and culture. Khmer students identified this institution as concentrating on Vietnam's religious and cultural heritage at the expense of their Khmer traditions, without necessarily providing them with an adequate Buddhist studies education.

The closure of the monastic route to Cambodia also closed down the most convenient option available to Khmer people wishing to advance their education in non-religious subjects. In 2003, I spoke to a monk in Wat Chantarangsay in Hồ Chí Minh City who was undertaking studies in computer science and English in an urban university. To gain entry to the university, he had to study in the Vietnamese state system for 12 years, in addition to the many years he had studied as a monk in the Khmer and Buddhist system. Around that time, scores of Khmer monks were accessing secular Vietnamese higher education in this way. However, the temple where he was staying - one of only two Khmer wats in the city - was small and crowded, and he found learning the Vietnamese language difficult. He told me it would have been much easier for him to study in Cambodia, whose proximity, shared language and culture, and large number of temples, colleges and alms-providing laypersons in its urban centres made it an ideal place for Khmer youths to further their studies.

The closure of the educational path to Cambodia deprived the Khmer Krom monastic education system of well-trained teachers. Although individual monks can and do make their way to Cambodia, it is very hard for them to return home. If they do return, they must disrobe and are not allowed to teach. Similarly, teachers and monks from Cambodia are not allowed to teach in Khmer monasteries in Vietnam. Hence in the 1990s to the late 2000s, monastic educators were drawn exclusively from people who had studied in Cambodia prior to 1975, or those who had studied in Khmer temple schools in Vietnam at most to high school level. As a result, Khmers in Vietnam were denied the opportunity to interact with teachers with advanced religious or secular knowledge or functional literacy in their own language. Increasingly, Khmer students in Vietnam were taught by teachers whose only knowledge of written Khmer came from the small set of textbooks used in the monastic classroom. 
Many people I spoke to bemoaned the deterioration in the intellectual capacity of the Khmers in Vietnam that these policies have brought about. A senior monk in Hồ Chí Minh City with whom I spoke in 2010 was despairing about his people's low educational level:

Khmer Krom students are far from meeting international standards and from gaining admission to study overseas. Hardly any Khmer Krom students have MAs or PhDs.

Their level of Pali and religion is also very low. All of the talented, knowledgeable teachers have died. Some have gone overseas. No one is left to pass on knowledge to the next generation. Because there are so few knowledgeable monks and achars left - educated achars are working in the rice fields - there are few people who could teach the next generation or guide the development of a better educational system.

Trà Vinh alone has a strong Pali and Buddhist studies program. In the provinces of Cà Mau, Kiên Giang, and An Giang, such a program is practically non-existent. But Trà Vinh is strong only in knowledge of the Pali sutras and monastic law. In these respects they are as strong as or even stronger than monks in Cambodia. Yet no new research is being done there or deeper investigation into the religion, language, and law. Quite likely there is not a single Khmer monk in Vietnam who could prepare an original composition in Pali - for example, describing the layout and activities of a typical Khmer temple. On the other hand, Thailand has scores of people who have done in-depth $\mathrm{PhD}$ research into Buddhism.

By contrast too, Vietnamese Mahayana students study to a high level, have PhDs, do research, hold conferences, study abroad, and they have good access to and do well in secular subjects as well.

Ultimately, the closure of the route to Cambodia threatened to have an impact on ordinations. Until the mid-1970s, ordination in Vietnam provided monks with knowledge that had utility in neighbouring Cambodia. It provided rural youths with a way to loop through Cambodia's urban centres, where they could deploy their knowledge to their advantage or accumulate more to repatriate to their home communities. Denial of these opportunities led to the marginalisation of ordination in Vietnam as a means for Khmer social and economic advancement. Related to this was students' lack of any sense of where their education might take them, or how it might relate to a world beyond their villages, given that the border to Cambodia was 
closed after 1975. Lacking these elements, Khmer monastic education in Vietnam risked becoming a closed system that failed to bring in any new ideas. Unable to engage with the outside world or change with the times, Khmer monastic education was in danger of becoming sterile and defunct.

\section{The Search for a Peak Educational Destination}

The closure of the border to Cambodia had major implications for the survival of the monastic education system and for Khmer cultural reproduction in Vietnam. It denied Khmer intellectuals in Vietnam access to the perceived source and centre of their culture. It terminated a well-trodden educational route that Khmer students in the Mekong Delta had taken to the peak destinations of their vernacular tradition. It denied Khmer communities in Vietnam access to a means by which their members had long been able to gain local distinction and attain leadership, thus closing down a traditional avenue of social distinction within the Khmer-speaking world of Vietnam. It also undermined the entire Khmer monastic system in Vietnam, threatening to make it obsolete as the vestigial launch pad for a leap into higher learning and social position.

The closure of the monastic route to Cambodia created serious problems for Vietnam as well. Although the government had permitted the reopening of monastic schools and turned a blind eye to the illicit importation of Khmer-language textbooks, the ban on monastic educational travel to Cambodia became a focal point of ethnic Khmer dissatisfaction with the government. Ever since I began my research in 1999, complaints about this measure have been intense, bitter, and consistent. The bans were cited widely as proof that the Vietnamese government lacked interest in Khmer culture, educational self-improvement, freedom of religion and mobility, local tradition, and the sanctity of monks. The removal of a peak destination for education was taken as evidence that the government's plan for its Khmers was to keep them ignorant and to stifle the emergence of selfaware, conscious, and enlightened Khmer individuals, thereby making it easier to assimilate the Khmers. 
In 2006, in apparent response to these concerns, the Vietnamese government moved to set up a high-level Khmer Buddhist Studies Institute in Vietnam that would teach Buddhist and Khmer studies subjects at the university level. Several high-ranking Khmer abbots in provinces of the western Mekong Delta are credited by their peers with pushing forward this initiative. The site selected for the institute was in Ô Môn District of Cần Thơ Province, a rural fruit-growing area of formerly dense Khmer settlement not far from the Bassac River whose Khmer population had largely been dispersed by the wars from the 1940s to the 1970s. Its main campus was in Wat Polthisomrong, a temple beside the Ô Môn market with very small grounds, where a dormitory of 23 bedrooms and some small classrooms were constructed in 2007. A second campus was designated in Wat Sanvoar, just a kilometre or so away, in a rural area whose lower population density and available land would allow the school to expand in size.

The institute was officially opened in mid-2007 when the first intake of 63 monks began their four-year higher-level Khmer and Buddhist studies course. The students came from many provinces; over a third were from Trà Vinh. All of them were ordained monks. They had already studied for at least five years in monastic schools and had a strong foundation in Pali, Khmer, and religious subjects. ${ }^{10}$ The eight or so teachers came from several provinces, mostly from Sóc Trăng. Two of the teachers from Trà Vinh had undertaken MA-level Buddhist studies overseas. ${ }^{11}$ The curriculum comprised 25 subjects. They included a variety of religious subjects, no less than six language subjects, some computing, history, and social science subjects, and subjects on Khmer culture, arts, and literature. ${ }^{12}$ The students told me that English and Sanskrit were the most difficult subjects for they had little prior exposure to them. The students in the first intake finished their degree in 2010 with exams and a mini thesis.

Abbots in the Ô Môn area played a leading role in mobilising funds and labour for construction of the school buildings in Wat Polthisomrong. Much of the labour to build the dormitory and classrooms was

10 According to the students with whom I spoke at the institute in July 2010, the numbers of students by province were: 24 Trà Vinh; 12 Sóc Trăng; 9 Kiên Giang; 9 Vĩnh Long; 3 Cần Thơ; 2 Bạc Liêu; 2 An Giang; 1 Hậu Giang; 1 Cà Mau.

11 One teacher did his MA in Buddhism in Sri Lanka, the other did his MA in Buddhism in Maha Chulalongkorn, Thailand.

12 The languages studied were Thai, English, Vietnamese, Sanskrit, Pali, and Khmer. 
contributed by local laypeople, with fees paid to building contractors only for specialised tasks. A contribution of $\$ 1,000$ AUD was made by a Khmer family in Australia. Contributions were also made by Khmer Krom now living in America and Canada. Locals also chipped in. The Abbot of Wat Polthisomrong told me that some single donations of \$100-200 AUD made by local families were major contributions, given local families' limited means. He said the government also had promised to match those funds obtained from Buddhist laypersons. If followed through, he said, the contribution from the government would be 50 per cent. The state also granted some 10 or 12 hectares of land to the school at the Wat Sanvoar campus to construct a larger and permanent facility.

There was some pride and optimism among Khmer Krom abbots and monks at the founding of this institute, which bore the name 'The Khmer Buddhist Studies Institute of Southern Vietnam' (in Khmer, Wicia Stan Butisasana Khmer Vietnam Khang Thbon). One leading abbot said it was one of just four Buddhist institutes in Vietnam, the others being in Hà Nội, Huế, and Sài Gòn. It was the first universitylevel institute for Khmers in Vietnam. Before it was founded, Khmer monks who wanted to study to a higher level had to attend the Vietnamese Buddhist University in Hồ Chí Minh City. The leading Khmer abbots of the three largest Khmer-populated provinces were on its governing board. One of them, who said he was the deputy head of the institute, told me with emotion that its founding showed how much the Communist Party of Vietnam cared for Khmers.

Nevertheless, the institute has also attracted widespread criticism from Khmer Krom monastic leaders and educators. Most lamented the small size of the school, cramped in the grounds of one of the region's smallest temples, which greatly restricted the scope of the school, leaving no space for it to develop. Several also commented to me on the length of time it was taking to establish a larger and more permanent facility on a second campus, giving rise to a view that official commitment to the institute was diffident. Many suggested that the government had skimped in its support for the project by selecting an obscure location where the land was cheap and relying on co-contributions from poor Khmer laypeople. Development of the new campus was delayed by lack of government funding. Also indicative of official disinterest was the lack of people with higher-level degrees to teach at the institute. If better teachers were to be found, Khmer people would have to 
come up with the money themselves to send people overseas to gain an appropriate education. Meanwhile, the institute is not given the money it needs to recruit adequately trained teachers.

The main criticism of the institute was its location in a remote rural area, which was a matter of universal disappointment and occasional despair. Those I spoke with considered it strange and inappropriate for such a high-level institute to be based in such a location. Acceptable facilities or services are not available locally to support universitylevel studies. All of the teachers have to be brought in from outside, and few quality teachers could be attracted to reside long-term in such a remote location. Just as importantly, no other colleges are available locally that could extend students' range of study options. The present campus is deep in the countryside, away from anywhere that high-level Khmer students want to be. They already have spent their whole lives in the countryside and the present location does not allow them to expand their knowledge in line with the challenges and imperatives of a modern society. The site is not even in a Khmer neighbourhood, which limits its integration into Khmer social and cultural networks, and it is situated far from the demographic centre of the Khmer population in Vietnam.

All of the leading Khmer monastics I consulted thought that the institute should be in the centre of a major city where there is better access to books, services, and teachers appropriate to the range of courses taught at this high level. All thought Hồ Chí Minh City (Prey Nokor) was the most appropriate place. This was what originally had been proposed. The leading abbot of one province told me that after conferring among Khmer monks and abbots, the South Vietnamese Khmer Buddhist monks association proposed to Vietnam's Religious Affairs board (Ban Ton Giao) to establish the Khmer Buddhist Studies Institute in Hồ Chí Minh City. However, he said:

The board rejected the proposal, as did the People's Committee of Hồ Chí Minh City. They said the proposal would cost too much. Sài Gòn lacked space and the land for the institute would be too expensive. Instead, they suggested that the institute should be better located in Cần Thơ, which is the economic and cultural hub of the Mekong Delta and in the middle of all the provinces where Khmer people live. Eventually, however, the site selected was not in Cần Thơ City but in the countryside, 20 kilometres away from Cần Thơ. Ô Môn is not in any way a hub for the region. Why put it in Ô Môn rather than closer 
to the centre of Cần Thơ where far better teachers and services would be available and monks would be able to study other subjects like computing, English, and the like in urban college campuses?

Several senior monks vented their frustration at the government's response to their suggestions for the location of the high-level Khmer institute. Leading abbots told me that they had put the suggestion to the Committee for Ethnic Affairs (Ban Dan Toc) to locate the university in a major city, but they were not heeded. This committee and the religious affairs committee were the responsible authorities. The National Buddhist Association was not helpful either, nor were the metropolitan governments. One monk assured me that '10 out of $10^{\prime}$ abbots will tell you that they are sad about this outcome. Many abbots continue to insist that the Vietnamese government can and should find the money to build a campus in either Hồ Chí Minh City or Cần Thơ. Perhaps the best indication of the unpopularity of the government's initiative is that the second intake of students at the Institute in Ô Môn, in 2011, consisted of just 30 students.

\section{The Thai Connection}

Khmers are not permitted to travel abroad to study. If they are desperate to do so, they can sneak across the border with Cambodia. But then they have to sneak back as well. Either way, if the police catch them, they will be thrown in jail for a very long time. The government says that those Khmer travelling abroad are seeking to engage in 'politics'. But Vietnamese are free to do so.

This criticism was delivered to me in 1999 by a monk in one of the biggest monasteries in Trà Vinh Province. In this and following years, I frequently heard Khmer monks speak of the serious lack of educational opportunities that Khmers in Vietnam confronted both in their traditional monastery system and the state system. Many people I met, old and young, conveyed to me their sentiments of intense anger at the oppression and mistreatment to which Khmers were subject, and their despair about the imminent demise of Khmer identity and culture. Abbots and monks sketched a claustrophobic scenario of being entombed within a Vietnamese-dominated world in which, slowly but surely, they were being suffocated. 
However, this monk offered a ray of hope. He showed me the picture of one local monk who had managed to make it to Thailand. He was depicted studying Buddhism in a class of Thai monks. My host said indeed this individual had made it to Thailand, but he was not able to return.

In the early 2000s, I began to hear stories about Khmer monks who were studying Buddhism in Myanmar, Sri Lanka, Thailand, and even further afield. Persistent stories were told of one monk from Trà Vinh who was studying Buddhism in Sri Lanka. The abbot of another monastery was studying Buddhism in Myanmar. The legal status of these educational journeys was unknown. However, people speculated that the Vietnamese government would allow Khmer students to study in Myanmar because, like Vietnam, Myanmar had an authoritarian government that restricted freedom of expression and therefore Khmers residing there could not learn or say anything that was critical of the situation of the Khmers in Vietnam. Sri Lanka was so far away that monks who were studying there posed virtually no threat to the government.

The exploits of these monks were the subject of much discussion and admiration. One was described as a genius. He was noted for his exceptional intelligence, knowing five to six languages, some of which he had been able to master in a matter of months. In one week he had been able to learn the contents of an entire three-month course in computing. Another story, told to me in 2003 by student monks in Wat Somroang Ek, seemed to muddle the details of another monk's educational itinerary. The abbot of their monastery, they said, had been studying overseas in Canada for three years. He had completed the 12 years of Pali education in Trà Vinh, graduated from Year 12 of the state system, spent several years studying in Sài Gòn and in Hà Nội, studied for three years in Myanmar, and, they thought, he also had studied for a few years in Australia. 'His life is devoted to education alone.' They estimated that he had spent 30 years of his life studying.

The stories engendered an outpouring of hope. They outlined a potential pathway of educational mobility. They suggested that, by ordaining and studying Buddhism, it was possible to make it overseas; foreign locations were accessible, and they were attainable to those with the aptitude and dedication. The stories of these successful 
overseas educational journeys alleviated many Khmer people's sense that their lives, consciousness, and futures were to be confined exclusively to what Vietnam had in store for them. The possibility of studying abroad, however remote it may have been, captured the imagination of a great many monks and inspired in them the ambition to eventually make it overseas to study Buddhism. So many times did I hear monks express the aspiration to study overseas that it cannot be discounted as a significant factor behind the decision of many to ordain and to persist in the program of monastic studies.

In the mid-2000s, I began to see signs that the dream of overseas study was being realised. The new focus was Thailand. In 2006, I spoke with a group of monks in a monastery in Trà Vinh town. The monks wanted to practice English with me. One from Trà Cú had been ordained for ten years. His English was very good. He was also learning Thai and told me that he was planning to go to Thailand to study Buddhism for three years. When I returned to the temple the following year I was told that two of the monks I had met last time had departed for Thailand. Three of the monks were now speaking quite good English. They would also go to Thailand. 'This is a new place to study', they said. 'Five years ago, no Khmer monks were studying in Thailand.'

Increasingly, I heard stories of monks from a range of temples in Trà Vinh who had gone to study Buddhism in Thailand, or were preparing to do so. In 2006, monks told me that $12 \mathrm{Khmer}$ Krom monks were currently studying Buddhism in Thailand. In September 2008, I was told that altogether 50 monks from Vietnam were studying in Thailand. In January 2013, the leading abbot of Trà Vinh Province reported that so far, over 100 students from Trà Vinh had studied in Thailand. The most popular destination is the Buddhist University Maha Chulalongkorn, in Bangkok, although Khmer Krom monks have also studied in universities in Chiang Mai and Surin.

The attraction of Thailand as a higher education study destination lies in the perception that Theravada Buddhism has reached a uniquely high level of development in that country. Monks told me that Thailand is a good place to study Buddhism because Buddhism is the state religion of Thailand and Buddhist education thus receives strong patronage from the state. New research is being done there, for example, transcription of the Pali sutras which are held in abundance in Buddhist monasteries, and deeper investigation into the religion, 
language, and law. Thailand has many people who have done $\mathrm{PhD}$ research into Buddhism. The country also appeals as a global centre or hub for Buddhism. One monk who was planning to study in Maha Chulalongkorn told me that this university teaches monks from Myanmar, Laos, Cambodia, Thailand, and Sri Lanka.

Nonetheless, it is clear that what is sought in these educational pilgrimages is broad-spectrum knowledge in secular subjects as much as of Buddhism itself. The opportunities it presented to study English and other non-traditional subjects at a high level was an important reason for Thailand's appeal. Monks in their early 20s in Wat Kompong Nikrodh said that the advantage of studying in Thailand or Myanmar over Cambodia is that the language of instruction is English. As the senior Pali teacher of another important Trà Vinh monastery told me:

Four of my former students are now studying in Thailand. They have sought permission to study there for four years. They live in a monastery, still ordained as monks, and study English in a college in Bangkok. That is what they are there for. They want only to study 'outside' subjects like English, especially, and computing.

Thailand is considered a modern, sophisticated country where the quality of teaching is high. In 2010, I met a monk in rural Trà Vinh who had studied in Thailand for four years. He spent two years in Chiang Mai and two years in Maha Chulalongkorn. He studied English, Thai literature, and Buddhism. 'In Thailand, Buddhism is very advanced. The quality of teaching is high.' He had many foreign teachers in Chiang Mai, spoke English remarkably well, and was now teaching it in his home temple.

Another factor that works to the advantage of Thailand is the pressure the Vietnamese government is under from Khmer Krom people to provide them with reasonable educational options. As one monk noted, many monks yearn to study in Cambodia, where they can study in Khmer and take both Buddhist and non-Buddhist subjects. However, Cambodia is closed off as a path for higher studies because of political conditions. Internally, the government has been far from successful in providing an option of equivalent quality for higher-level education in Khmer studies or Buddhism. And few Khmer Krom monks are attracted to studying in Vietnam's own Buddhist universities, because of the markedly Vietnamese flavour of the curriculum, and Khmer monks' perceptions about discrimination within Vietnamese Buddhism 
against Khmer Theravada monks and practices. As student monks in a Trà Vinh monastery noted, the Vietnamese government is forced to allow monks to study in Thailand since it has failed to provide any other alternatives for their higher education.

Also having an effect on monks' study destinations are shifts in Cambodian official policy. Monks in Phnom Penh told me that, prior to 2007, monks from Trà Vinh frequently snuck across the border to Cambodia to continue their Buddhist education at high school and university levels. This illicit movement was tolerated by the Cambodian government, and the Cambodian Sangha abetted the flow by recognising the monastic studies program in Trà Vinh as a prerequisite for entering Cambodia's Buddhist universities. The peak was around 2007, when there were perhaps as many as $300 \mathrm{Khmer}$ Krom students in monastic schools in Phnom Penh. However, demonstrations by Khmer Krom student monks in both Vietnam and Cambodia in that year led the Cambodian government to restrict the flow. The Cambodian Sangha withdrew its recognition of the Khmer monastic studies program in Trà Vinh as a prerequisite for higher-level studies in Cambodia. Monks told me that this had an immediate effect on the flow of Khmer Krom monks to Cambodia to undertake higherlevel Buddhist studies. Now it is only Thailand that recognises the Vitchear Alai (high school) qualification in Trà Vinh, so many monks from Trà Vinh go straight into Buddhist university in Thailand.

A leading abbot of Trà Vinh Province told me that Thailand is the route preferred by the Vietnamese government for Khmer Krom monks to pursue university education. The state issues permits and passports to students, and it is easy for them to return to Vietnam to teach and work since this route is officially sponsored. It is also the path promoted by Vietnam's Khmer Buddhist association as the best option available at the present time. One of the reasons for the association to promote this route is to build up a cadre of teachers who will be able to teach in the temple schools.

The principal factor that puts a limit on studying in Thailand is the cost. Since the youths who take this route are exclusively from impoverished rural families, usually with only a fraction of a hectare of ricelands to their name, they have to rely on outside sources of funding. The first Khmer Krom monk to study overseas in the post-war years was sponsored by laypeople in the United States. He did his 
English-language MA in Buddhist philosophy at the Buddhist and Pali University of Sri Lanka (established in 1981) in Colombo, and lived in Sri Lanka for nine years. He was ordained as a monk the entire time, staying in a monastery in Colombo. Many of the students who travel to Thailand similarly must rely on sponsorship from a wealthy layperson. Student monks from one famous temple in Trà Vinh told me that the abbot has paid for students to study in Thailand. But they are under bond. After returning from Thailand, the monks must teach in the temple for an equivalent length of time to repay the debt. Some excellent students also receive sponsorship from the Theravada Buddhist monks association.

However, as monks who contemplate the alternatives frequently observe, the problem with Buddhist higher education overseas is that one has to be wealthy to pursue it. If one is not among the few supported by the association, one has to pay transport costs, which are very expensive. Local institutions may allow monks to stay in the temple for free and one can rely on the alms round for meals, however, a host of additional expenses exist, such as for supplementary food and drinks, study materials, fees for additional study, and water and electricity fees. To prepare for study in Thailand, a monk has to study English and Thai for several years and arrange his own papers. Unless he finds a generous sponsor, a typical rural youth cannot afford these studies.

Nonetheless, the opening of a path to higher education in Thailand has had notable revitalising effects on the Khmer monastic program in Trà Vinh. It charged the whole enterprise with newfound purpose for monks to know that their studies in local monasteries had currency in the world beyond. Ordination provided them with the means to attain distinction according to criteria which had universal significance, and gave them hopes of gaining access to an arena of prestigious modernity. For a people who consider themselves imperilled by the Vietnamese institutions that envelop them, Thailand offers an escape route, an alternative path for development and self-realisation that is felt to be autonomous from the designs of the Vietnamese state. It also has unleashed unexpectedly a boom in the study of the English and Thai languages in temples deep in the countryside. And it gave new rigour to the study of Buddhist subjects, for these were to be emphasised in the Thai monastic curriculum. 
This new pathway also has significant limitations. As already noted, such travels are not subsidised by the state, and the high cost of getting to Thailand means that only a few community-supported positions are available each year. Additionally, the investment in money and time in studying English and Thai are considerable, and put the option beyond the reach of the vast majority. All said, the Thai option is significantly more costly and less accessible than the traditional path to higher education in Cambodia, which is closer and does not require additional linguistic preparation. However, the major disadvantage of studying in Thailand is that it does not provide any opportunities for studying Khmer at a higher level, learning more about Khmer culture and history, or gaining practical experience in Khmer as a sophisticated functional language. One leading abbot who was instrumental in forging the option of studying in Thailand confided to me his regrets that the emphasis in Thailand is on studying Buddhism, while there is no emphasis on historical and Khmer cultural heritage subjects. Such a pathway therefore runs the risk of turning the Khmer monastic education system in Trà Vinh into a foundational religious studies course, rendering as extraneous the Khmer cultural literacy subjects that many believe to be the most crucial elements of the monastic studies program.

\section{Pilgrimages to the Cultural Centre}

Considering the inadequacies of these options for higher monastic education, it is not surprising that many student monks in Trà Vinh continue to regard Cambodia as the best destination for undertaking higher-level studies. Despite the illicit nature of such journeys, the likelihood of being arrested or surveilled on one's return, and the risks to employment opportunities and one's status as a monk, many student monks choose to make the journey. It is widely known in Trà Vinh that many monks have left for Cambodia to undertake higher-level studies. One of the top abbots in the province, who holds an important official position, described it as the 'private route' (pleu aecachun), deliberately refusing to call it illegal, but distinguishing it from the officially sanctioned route to Thailand. He had no doubt that more monks from Trà Vinh were studying in Cambodia than in Thailand 
or elsewhere, and he told me calmly that this was understandable, since Cambodia was the traditional destination for monks from this province to pursue their higher-level studies.

Over a period of years of visiting Phnom Penh, I met many Khmer monks from Vietnam who were studying in the capital city's higher education institutions. Most came from Trà Vinh, although monks from Vĩnh Long and Sóc Trăng were also well represented. I could not obtain official statistics, but in 2012 the consensus was that several hundred Khmer Krom monks were currently enrolled in educational institutions in Phnom Penh. They resided in many monasteries, some of the largest concentrations being in Wat Maha Muntrey, Wat Potum Wattey, Wat Somraong Andeth, Wat Unnalom, Wat Tuol Sangke, Wat Uttara Wattey, Wat Langka, and one unregistered Khmer Krom temple. Like the many thousands of student monks from rural Cambodia residing in Phnom Penh monasteries, the monks observed standard monastic routines while also studying full time. Some were repeating Buddhist secondary school years in the temples, while others were undertaking educational programs outside the wat. They were enrolled in a remarkable range of undergraduate and graduate programs, including in Phnom Penh's two Buddhist universities, and in numerous secular state and private colleges and universities where they studied a great variety of subjects.

Every one of these intelligent and serious people, the cream of Trà Vinh Khmer society, had crossed the border into Cambodia illegally. Their stories of cross-border travel were frequently adventurous. The story of Luk Sone provides an example.

Luk Sone resides in one of Phnom Penh's famous inner city temples. He comes from Trà Cú District in Trà Vinh. He is the oldest of seven children. His younger brother, a lay student, is in the temple with him. The rest of his family is back at home. He came to Cambodia in 2002 because he wanted to study at a university. The quality, level, and resources for Khmer education in Vietnam were too low for him to study further than the fourth year of the Butikah Saksa program. When he crossed the border, he went with a travel organiser, to whom he paid 900,000 VND to arrange his travel. He went in a group by bus. When he got to the border, he removed his upper torso robe and put on a shirt, coat, pants, and a hat to conceal his monastic appearance, keeping on only his lower body robe - by keeping that on he 
remained ordained. He did not carry travel papers. Some of the money he paid was used to facilitate informal cross-border passage arranged by the tour operator.

All of the Khmer student monks I met in Phnom Penh had crossed the border furtively, avoiding the border posts by detouring around them or by disguising their monastic identity. They were reluctant to describe the specifics of their journeys when other monks were present, either explaining that it was very difficult to talk about the topic, or falling silent when I probed for details.

The Khmer Krom student monks I met in Phnom Penh in 2009-13 were products of the monastic education program in Trà Vinh. Most had been monks for over 15 years, having first ordained in the mid-1990s. The typical biography was of a man from a poor rural family who ordained in his early to mid-teens, having already studied Khmer literacy in the temple in the evenings or summer breaks, or while engaged as a temple boy (khmeng wat). After a year's probationary ordination, they had entered the monastic program, completing both the intermediate and high school stages, or seven years in total, in the period between 1995 and 2005. Some then continued teaching literacy or higher-level subjects in their home temples. They were good students and were ambitious to study further, but had reached the upper limits of the Khmer-language monastic education available in Vietnam.

Like Luk Sone, many told me that they had come to Cambodia in order to continue Buddhist studies at the university level. Members of this cohort had completed their monastic schooling in Vietnam prior to the founding of the Khmer Buddhist studies institute in Ô Môn or the opening of the path to Thailand as a viable destination for universitylevel studies. Several of them had enrolled in one of the two Buddhist studies universities in Phnom Penh - Preah Sihanouk Reach, run by the Mahanikay order, and Preah Sihamoni Reach, run by the Thommayut order - both located close to the Royal Palace. Each had a four-year undergraduate program which taught standard subjects such as the monastic code, Pali-Khmer translation, and Buddhist history - at a deeper level than was taught in Trà Vinh — along with subjects such as philosophy, Sanskrit, comparative world religions, and Buddhism in Khmer literature, which, prior to 2007, were not taught in Vietnam. They each also offered graduate level studies 
which required students to complete a thesis under supervision. Hence these students' reason for coming to Cambodia was to progress to a higher level of study than was locally available, in a place, format and language accessible to poor rural youths, and in a locality that for generations had been a peak destination for Khmer-language monastic education.

Also prominent among the reasons given for travelling to Cambodia was to undertake studies in secular subjects. I met Khmer Krom monks in Phnom Penh who were enrolled in English, accounting, computing, tourism, agricultural development, and educational management courses at the undergraduate and graduate levels. Their opportunities for studying such subjects in Vietnam were practically non-existent. Coming from Khmer-dominated rural areas of the Mekong Delta, where state schooling at all levels was weakly developed and of poor quality, most had only elementary-level Vietnamese schooling, and their Vietnamese language was very basic. The tough entry requirements, costs, and distance and unfamiliarity of Vietnamese colleges and universities posed intimidating barriers to gaining a high-level secular education. By contrast, such options were within reach in Cambodia, where student monks were supported by laypeople and resided free of charge in temples close to a range of educational institutions which used their mother tongue as a language of instruction. As in Thailand, the monkhood served as an avenue of social mobility for poor rural youths who would otherwise lack opportunities for worldly advancement (Wyatt 1966; Tambiah 1976). Such instrumentalist reasons were not inconsistent with monastic vocations for, as one monk put it, the essential purpose of ordination is to gain knowledge.

For many Khmer Krom students, Cambodia beckons as a cosmopolitan centre, a place where foreigners brush shoulders with Khmers, where international languages are widely spoken and can be learned easily. One monk from the backwater village of O To Tung in Kompong Spien had been in Phnom Penh for six years. When I met him in 2012 he had been studying English for four years. He told me that his primary reason for coming to Cambodia was to study English, and explained how he had come to this decision: 'When I was ordained, some monks from my home temple came home from Cambodia to visit and they were speaking in fluent English. It created a strong impression in me and I wanted to speak this language as well as them.' 
A significant underlying reason for monks wanting to undertake higher education in Cambodia in either the 'religious' or 'secular' streams is the unique opportunity it provides to improve their capacity in their native language. Courses and assignments at this level push students to a very high standard of written and spoken Khmer, take them into specialised realms of expression and vocabulary not commonplace in rural communities, give them knowledge of the etymological roots of their language, and expose them to new expressions. In addition to the huge range of texts used in the classroom is the plethora of media, popular books, and signage all around them in this Khmer cultural metropolis. This is a highly significant factor for students for whom the only examples of Khmer writing are the handful of photocopied texts from Cambodia used in temple schools. Khmer people in Vietnam live in a social environment devoid of written Khmer, where Khmer is a pedagogic language rather than a language of functional cultural citizenship, and where all debates, laws, and discussions are conducted in Vietnamese. Students value the depth, breadth and dynamism of this rich and immersive linguistic experience and access to the metropolitan centre of their language.

More important still, and common to all students, is the nature of study in Cambodia as a quest for cultural identity. Many of them expressed doubts about the integrity of the Khmer monastic education program they had been through in Vietnam. A monk who had come to Cambodia to study in the secondary level of the monastic curriculum told me:

The most important subject for me is Khmer. It is the main reason I came here to study. In the monastic studies program in my province, Vietnamese language and content are mixed in with the Khmer curriculum. Few books in Khmer language are available for study or deeper research. And one cannot study subjects such as Khmer geography or history. Thus Khmer people cannot learn about their origins [daem kamnaat], their identity. Also, Khmer morality and culture are not taught unlike in the monastic curriculum in Cambodia. The quality of monastic education is higher in Cambodia. Classes in the monastic curriculum are broader [bauk tu lie chien].

Another monk had completed 12 years of the Khmer Buddhist monastic curriculum in Trà Cú District Trà Vinh, epicentre of the Khmer studies program. He then taught what he had learnt to novices and young Bhikku in his temple. After three years he wanted to study further, 
so he asked his abbot for permission to travel to Cambodia, and the abbot agreed. He did not ask permission from the authorities, because they would not grant it. So he crossed the border illegally:

I wanted to study in Cambodia because the Vietnamese government tightly restricts what can be learnt in Khmer schools. In fact, only seven subjects can be taught in the monastic high school in Vietnam, half as many as in Cambodia. Several subjects are forbidden, such as history and geography. And the content of the allowable subjects is greatly restricted. The depth and breadth of subjects in Cambodian schools is much greater. I know this because I have studied in both places. The Vietnamese government does not want the Khmer Krom to know about their history because if they do they will feel anger, sorrow, pity and will demand to do something about it. They will join together to ask for their country back.

I spoke with several abbots and university lecturers in Phnom Penh temples who agreed Khmer Krom monks had a mixture of motivations for studying further. However, the most pressing one is to learn more about their culture, their language.

One senior monk who lectures at Preah Sihanouk Reach Buddhist University said that there are many Khmer Krom students at his university. 'They are more accomplished [boukae] than student monks from Kampuchea. They work very hard. Most monks from Kampuchea Krom want to study in Cambodia.' The Khmer Krom students at his university come from all provinces of Kampuchea Krom. Those from Trà Vinh (Preah Trapeang) are highly represented. He commented:

The monks in Preah Trapeang are very strong [khlang]. They are like Buddhist soldiers. Their desire to protect their culture is very strong. They have a sense that they alone can prevent the loss of Khmer culture. Girls too study in the Buddhist program for the same reason. It is quite rare for girls in rural areas of Cambodia to attend the Buddhist studies program.

We can see that Cambodia continues to act as a powerful magnet for Khmer Krom monks who see it in multiple respects as a highly desirable educational destination. The knowledge that can be obtained in Cambodia is judged to be broader, deeper, and more reliable and pure than what can be gained in Vietnam. The educational pilgrimage to Cambodia provides self-knowledge about one's origins and language, and an immersive experience in modern Khmer cultural trends that 
cannot be obtained elsewhere, be it in Vietnam or Thailand. It provides exposure to contemporary and practical forms of knowledge that otherwise are inaccessible.

\section{Impossible Returns, Lasting Divides}

Having made the journey to Phnom Penh for an education, many Khmer Krom see no reason to return to Vietnam. For instance, one person from Bạc Liêu came to Cambodia because he wanted to study English. He told me that the quality of English teaching and learning in Cambodia is much better than in Vietnam. He came as a layperson and ordained for eight years while studying, because he wanted to be a monk. Ordination also allowed him access to free accommodation in a conveniently located urban temple, as well as donations from laypersons. Then, when he graduated, he left the monkhood, married and bought a house in the suburbs of Phnom Penh. He now works selling medicinal oil (prieng ktchol) in various places in the capital.

A monk from Vĩnh Long, residing in a central city temple, told me that the quality of secular education in Cambodia is better than in Vietnam. That, in addition to the paucity of Khmer-language books and the lack of a robust university-level Buddhist studies course in Vietnam, is why he came to Phnom Penh to study, crossing the border illegally to do so:

For Khmer Krom, it is easier to get a good education in English and other subjects in Cambodia than in Vietnam. Plus for Khmers there are many more work opportunities in Cambodia. For an educated Khmer person, it is very difficult to get good quality jobs in Vietnam.

He told me that he definitely will not return to live or work in Vietnam, even to retire, although he misses his family. One reason for this thinking was the lack of work opportunities in Vietnam. However, in addition, as a monk who has studied in Cambodia, he would be impeded in making a living in Vietnam - he would be suspected and restricted in obtaining work for the government, as a teacher, or in the business sector.

As this comment indicates, gaining access to this centre of knowledge has high costs. Having broken the law in crossing the border without official permission, student monks are unable to return to Vietnam. 
Monks say they would be arrested or persecuted by the police if they attempted to return. In all probability, it is not the small infraction of an illegal border crossing that makes them vulnerable to prosecution, but the threat they pose to the Vietnamese order. Having amassed new knowledge about their culture, history, and origins, they have made themselves into a resource that has the potential to threaten the prevailing regime of truth in their homeland. For them to display their cultural competencies in Vietnam would challenge the Vietnamese pedagogic order, for it would demonstrate that officially prescribed channels of educational mobility are not necessarily the best way for the citizens of the Mekong Delta to gain an education.

One of the unexpected consequences of this educational movement to Cambodia is that nearly all the monks who have followed this path have renounced Vietnamese citizenship, and have sought and obtained Cambodian citizenship and passports. They have charted plans for permanent residence in Cambodia, and have no intention to return to live or work in Vietnam. Superficially, this switch in citizenship might seem like a sign of their blind devotion to Cambodia, or to their own educational careers, and could be read as their abandonment of their Khmer compatriots who live in Vietnam. In actuality, the reverse is true. Ironically, it is the desire to return home to visit family, attend ceremonies, and maintain relations with their former teachers and peers that has led them to take out Cambodian citizenship. The only way they can return home and avoid persecution by the Vietnamese authorities is as the citizen of another country, under the protection of its embassy and of international law.

The ability for Khmer Krom monks to obtain Cambodian passports for travel to Vietnam appears to be a relatively new development. It possibly dates to around 2010, for I did not hear about it before then, and before 2010 I had never met a Khmer student monk in Vietnam on a return trip from Cambodia. However, in the years 2011-14, I met several Khmer Krom student monks who had travelled home on short visits using a Cambodian passport. They went to visit family, attend funerals, pick up funds, or attend the Khmer New Year, Pchum Ben, and Oc Omboc festivals. One told me he goes back once a year for about 10 days at a time. The experience is never comfortable:

I have been back to my village several times but only because I have a Cambodian passport. If I did not have it, I would be in big trouble with the police. Even so, when I visit, the police always approach me 
and ask all sorts of questions. The local police are contacted by the higher authorities and told that I am a bad person who committed a crime by leaving the country illegally. As a result, they always follow me and question me. You mightn't realise you are being observed when sitting, talking and laughing with a group of monks. But after you leave them, they are questioned by the police. As a result people are very reticent about what they say to me when I visit.

This was confirmed by another student monk: 'Now we have Cambodian passports, we can visit home, but are followed by police everywhere we go. This happened to me when I visited my home town for a week. I was followed every single day.'

While short, heavily policed home visits are allowed, student monks are deterred from making longer visits. None of them thinks it would be possible to return home to work as a teacher or in any other capacity. This assessment was echoed by a leading Cambodian Buddhist university lecturer who had worked with scores of such students:

Khmer monks from Vietnam who study in Phnom Penh never return to Vietnam to live and work. They can go back to visit for a few days but if they try to stay longer they are followed and questioned. They are suspected of being involved in politics and spreading information about history and forming a network with nationalists in Cambodia.

One monk told me that he would like to go back to Vietnam and teach, but the police would not allow anyone who has studied in Cambodia to do so, because such people know too much.

And what they know would cause their students to rise up and protest against the government. The government wants people to forget their history. It would be very difficult for him to return.

He knows of just one person who returned, but that person disrobed.

As a result of these acute sensitivities, a significant number of the most talented, ambitious, and knowledgeable Khmer Krom people have left Vietnam and are unable or unwilling to return. Pending a shift in Vietnamese government policy, which seems unlikely, those monks who travel to study in Cambodia are destined to remain there for the rest of their lives. In consequence, they are unable to repatriate their knowledge and experience, be that in Khmer culture, Buddhism, or other areas of expertise. This situation has led to the pooling on 
one side of the border of numerous culturally competent Khmer Krom people who are able to contribute to Cambodia's cultural and political life. On the other side of the border, Khmers in Vietnam lack a viable means to reproduce their cultural tradition and hence are deprived of the means to achieve cultural equivalence with respect to their counterparts in both Cambodia and Vietnam.

This comes as a significant cost to Vietnam, in the form of a brain drain affecting one of the country's largest minority groups, which loses the benefits of the social reinvestments that would flow from the return of these students and their repatriation of a variety of forms of valuable knowledge. In response, the Vietnamese government has had to build up an alternative infrastructure of secular educational institutions in order to replace what it has dismantled. At the same time, in order to counter the accusation that the closure of the educational route to Cambodia is designed to assimilate the Khmers, the government has had to keep in place a Khmer-language education system that mirrors the Cambodian national system. Ironically, the price to be paid for detaching the Khmer Krom from Cambodia's cultural sphere is tending to the faithful reproduction of Cambodian-style cultural institutions within Vietnam itself. It is difficult for the Vietnamese government to compete respectably on this terrain, and thus it is permanently vulnerable to the criticism that denying the Khmer Krom educational access to Cambodia has deprived them of access to social mobility, traditional and modern knowledge, religious expertise, and the ability to reproduce themselves socially and culturally.

\section{References}

Chandler, David 2008, A History of Cambodia (fourth edition), Silkworm Books, Chiang Mai.

Chealy, Chet 2009, 'Higher Education in Cambodia', in Yasushi Hirosato and Yuto Kitamura (eds), The Political Economy of Educational Reforms and Capacity Development in Southeast Asia: Cases of Cambodia, Laos and Vietnam, Springer, Netherlands, pp. 153-165.

Edwards, Penny 2007, Cambodge: The Cultivation of a Nation, 1860 1945, University of Hawaii Press, Honolulu. 
Geertz, Clifford 1963, 'The Integrative Revolution: Primordial Sentiments and Civil Politics in the New States', in Clifford Geertz (ed.), Old Societies and New States: The Quest for Modernity in Asia and Africa, Collier-Macmillan, London, pp. 105-157.

Hansen, Anne 2007, How to Behave: Buddhism and Modernity in Colonial Cambodia, University of Hawaii Press, Honolulu.

Harris, Ian 2009, 'Theravada Buddhism among the Khmer Krom', in Khmers Kampuchea Krom Foundation, The Khmer-Krom Journey to Self-Determination, Khmers Kampuchea Krom Foundation, Pennsauken, NJ, pp. 103-126.

Harris, Ian 2012, Buddhism in a Dark Age: Cambodian Monks under Pol Pot, University of Hawaii Press, Honolulu.

Kabilsingh, Chatsumarn 1986, 'Buddhism and National Development: A Case Study of Buddhist Universities', in Bruce Matthews and Judith Nagata (eds), Religion, Values and Development in Southeast Asia, ISEAS Publications, Singapore, pp. 62-81.

Kalab, Milada 1976, 'Monastic Education, Social Mobility and Village Structure in Cambodia', in David Banks (ed.), Changing Identities in Modern Southeast Asia, Mouton, The Hague, pp. 155-169.

Keyes, Charles 1971, 'Buddhism and National Integration in Thailand', Journal of Asian Studies, vol. 30, no. 3, pp. 551-567.

Keyes, Charles 1994, 'Communist Revolution and the Buddhist Past in Cambodia', in Charles Keyes, Laurel Kendall and Helen Hardacre (eds), Asian Visions of Authority: Religion and the Modern States of East and Southeast Asia, University of Hawaii Press, Honolulu, pp. 43-74.

Kiernan, Ben 1981, 'Origins of Khmer Communism', Southeast Asian Affairs, pp. 161-180.

Kiernan, Ben 1996, The Pol Pot Regime: Race, Power and Genocide in Cambodia Under the Khmer Rouge, 1975-79, University of California Press, Berkeley.

Malleret, Louis 1946, 'La Minorité Cambodgienne de Cochinchine', Bulletin de la Société des Etudes Indochinoises, vol. 21, pp. 19-34. 
Marston, John 2014, 'Reestablishing the Cambodian Monkhood', in John Marston (ed.), Ethnicity, Borders, and the Grassroots Interface with the State: Studies on Southeast Asia in Honor of Charles F. Keyes, Silkworm Books, Chiang Mai.

McDaniel, Justin 2008, Gathering Leaves and Lifting Words: Histories of Buddhist Monastic Education in Laos and Thailand, University of Washington Press, Seattle.

Société des Etudes Indochinoises 1903, Monographie de la Province de Tra-Vinh, Imprimerie L. Menard, Saigon.

Sovanratana, Khy 2008, 'Buddhist Education Today', in Alexandra Kent and David Chandler (eds), People of Virtue: Reconfiguring Religion, Power and Moral Order in Cambodia Today, NIAS Press, Copenhagen, pp. 257-271.

Stuart-Fox, Martin 1996, Buddhist Kingdom, Marxist State: The Making of Modern Laos, White Lotus, Bangkok.

Tagliacozzo, Eric 2013, The Longest Journey: Southeast Asians and the Pilgrimage to Mecca, Oxford University Press, Oxford.

Tambiah, Stanley 1976, World Conqueror and World Renouncer: A Study of Buddhism and Polity in Thailand against a Historical Background, University of Cambridge Press, Cambridge.

Taylor, Philip 2014, The Khmer Lands of Vietnam: Environment, Cosmology and Sovereignty, University of Hawaii Press, Honolulu; NUS Press, Singapore.

Wyatt, David 1966, 'The Buddhist Monkhood as an Avenue of Social Mobility in Traditional Thai Society', Sinlapakon, vol. 10, no. 1, pp. 41-52. 
This text is taken from Connected and Disconnected in Viet Nam: Remaking Social Relations in a Post-socialist Nation, edited by Philip

Taylor, published 2016 by ANU Press, The Australian National University, Canberra, Australia. 